\title{
Komunikasi Pemasaran Global Terpadu: Tantangan di Era Digital
}

\author{
SUNARTO PRAYITNO \\ Institute for Marketing Communications Studies \\ E-mail: sunarto.prayitno@yahoo.com | Hp: 08174935866
}

Abstrak Ditemukannya komputer, terutama internet, menyebabkan perubahan mendasar dalam konsep, strategi, taktis, dan implementasi pada bisnis, pemasaran, dan komunikasi pemasaran, yang bergeser dari kondisi pasar konvensional ke pasar modern pada era digital. Integrated Marketing Communications (IMC), merupakan suatu konsep hasil penelitian para praktisi dan akademisi dalam mengantisipasi kemandulan strategi lama yang sudah tidak dapat dihandalkan, dan menjadi paradigma baru yang patut dijadikan acuan dasar dalam menghadapi tantangan di pasar global. Penerapan konsep dan strategi IMC pada pasar global dikenal sebagai perencanaan Integrated Global Marketing Communications (IGMC). Perubahan-perubahan yang terjadi pada perilaku konsumen, pola pengembangan pesan, berkembang-biaknya media khususnya media digital, dan integrasi elemen-elemen komunikasi pemasaran merupakan dasar pengembangan rencana strategis (strategic plan) IGMC. Implementasi program IGMC dapat diharapkan menjadi 'peta jalan' menuju pencapaian kesuksesan organisasi atau perusahaan pada era digital. Paper ini merupakan hasil kajian rangkuman dari berbagai dimensi pemikiran para ahli, di samping analisis, interpretasi, dan theorizing penulis.

Kata kunci: Integrated Global Marketing Communications, Konsumen Global, Pengembangan Pesan Global, Penetrasi Media Global, dan Pola Perencanaan IGMC

Abstract

Discovery of computers and specifically the internet, led to fundamental changes in concept, strategy, tactic, and implementation of business, marketing, and marketing communications, which shifted from conventional to modern markets in the digital age. Integrated Marketing Communications (IMC) is a concept derived from the research made by practitioners and academics in anticipating the expiry of old strategies that are no longer reliable. In turn, IMC became a new paradigm to be used as a basic reference in facing challenges in the global market. The application of IMC concepts and strategies to the global market is known as Integrated Global Marketing Communications (IGMC) planning. Changes that occur in consumer behavior, message development patterns, the proliferation of media, especially digital media, and the integration of marketing communication elements are the basis of the IGMC strategic development plan. The implementation of the IGMC program can be expected to be a road map to achieve organizational and corporate success in the digital age. This paper synthesized the viewpoints of different experts and provides the author's analysis, interpretation, and theorizing.

Vol. 12, No. 1, Hal. 27-39 September 2021

Fakultas Ilmu Komunikasi Universitas Pancasila

Keywords: Integrated Global Marketing Communications, Global Consumer, Global Message Development, Global Media Penetration, and IGMC Planning Patterns

Accepted: 2 April, 2021

Revised: 24 June, 2021

Approved: 21 August, 2021 


\section{PENDAHULUAN}

To succeed in the $21^{\text {st }}$ century, global organizations must organize around customers and prospects and their operations and activities, not around geographies and certainly not around products and services (Schultz \& Kitchen, 2000). Untuk menjawab tantangan Abad ke-21-yang ditandai dengan perubahan mendasar pada seluruh tata kehidupan manusia akibat ditemukannya komputer, terutama internet-khususnya di industri bisnis, pemasaran, dan komunikasi pemasaran sebagai rangkaian aktivitas yang tak terpisahkan, juga ikut berubah drastis. Teori, konsep, strategi, dan implementasi konvensional yang semula mampu dihandalkan, dalam era teknologi informasi ini telah menjadi tumpul.

Diawali adanya keresahan 'orang-orang periklanan' yang menghadapi dan merasakan kerancuan kondisi pada akhir dekade 1980-an dan berlanjut ke decade 1990-an, berbagai benchmarking study dilakukan oleh para profesional pemasaran dari akademisi maupun praktisi tentang peranan integrasi dalam bisnis, pemasaran, dan komunikasi pemasaran. Salah satu hasilnya seperti yang dilaporkan dalam The IMC Best Practice Report, the American Productivity and Quality Center (Houston: APCQ, 1998), ditemukannya tahapan evolusi 'Integrated Marketing Communications (IMC), sebagai bentuk antisipasi perubahan kondisi yang terjadi.

Adapun empat tahap perubahan dalam evolusi IMC meliputi: Pertama, adanya koordinasi dalam implementasi taktis elemen-elemen pemasaran dan komunikasi untuk memeroleh konsistensi dan sinergi; Kedua, melakukan definisi ulang cakupan komunikasi pemasaran yang meliputi elemen pemasaran dan komunikasi yang berbasis customer insight dalam perencanaan programprogram komunikasi; Ketiga, pengaplikasian teknologi informasi dan penggunaan data pelanggan dalam upaya identifikasi, nilai, dan memonitor dampak integrasi program-program komunikasi guna memeroleh pandangan dari pelanggan (brand relationships); dan Keempat, menitik-beratkan pada kemampuan menggerakkan penggunaan informasi data pelanggan tahap awal (preliminary data) untuk mendorong 'corporate strategic planning' dalam membentuk infrastuktur informasi keuangan yang merupakan bentuk keselarasan antara program komunikasi pemasaran dan rencana keuangan perusahaan (Schultz \& Schultz, 2004:2033).
Adanya perubahan mendasar dalam perilaku konsumen di era digital akibat ditemukannya teknologi informasi, komputer, dan terutama internet, ikut andil besar dalam terjadinya pergeseran strategi pemasar dalam mengantisipasi kondisi pasar yang semula bersifat lokal (local marketplace) bergeser menjadi pasar global. Komunikasi Pemasaran Global Terpadu (Integrated Global Marketing Communications/IGMC) adalah suatu konsep pemikiran bukan sekedar program komunikasi yang dilokalisasi pada pengembangan pesan dan citra global yang disebarkan pada pasar lokal. Untuk mengembangkan program komunikasi pemasaran global terpadu, diperlukan adanya sejumlah keahlian, bakat, dan kemampuan dalam suatu organisasi/perusahaan yang berbeda dibandingkan strategi komunikasi pemasaran konvensional, dalam upaya mencapai kesuksesan bisnis di masa kini dan mendatang.

\section{TINJAUAN PUSTAKA}

\section{Konsumen Global}

Teknologi telah merevolusi bauran pemasaran, juga dalam pola segmentasi pasar, targeting, positioning, dan terutama apa yang menjadi ingatan dan pemikiran konsumen (customer retention) yang merupakan motif dasar terjadinya tindakan konsumen. Apabila konsumen menggunakan komputer, telepon genggam, bacaan elektronik, tablet, dan berbagai bentuk gadget lainnya, mereka 'memaksa' pemasar untuk menyediakan bermacam informasi yang tidak terbatas dalam upaya menjalin hubungan antara perusahaan dengan konsumen yang lebih efektif, dibanding dengan kondisi selama hari-hari sebelum Internet ditemukan. Maka, teknologi online telah menciptakan suatu 'nilai pertukaran' baru (Schiffman \& Wisenblit, 2015:26).

Konsumen sebagai elemen utama dalam pengembangan strategi komunikasi pemasaran modern, dewasa ini memunyai pengalaman yang berbedadengan saat strategi konvensional diterapkan. Secara tradisional konsumen dipandang dalam kelompok massa yang didasari pada klasifikasi geografi dan demografi, seperti tempat tinggal perkotaan, pedesaan, kelompok usia, jenis kelamin, kelas ekonomi sosial, pendidikan, dan tingkat penghasilan sebagai dasar segmentasi pasar. Sementara, kondisi psikografi konsumen, seperti aktivitas, ketertarikan, opini, dan gaya hidup konsumen sebagai suatu kelompok yang terkait dengan sikap individu terhadap suatu kategori produk, tidak banyak dijadikan fokus utama dalam segmen- 
tasi pasar (Prayitno \& Irwansyah, 2012:1150).

Saat ini, perilaku konsumen bergeser dari klasifikasi karakteristik sebagai kelompok massal lebih dilihat dalam ceruk yang bersifat khusus (niche market). Indikasi umum menunjukkan bahwa konsumen cenderung menjadi lebih individual, orientasi pada kualitas, mengutamakan kenyamanan, dan lebih selektif pada produk yang alami dan sehat. Sebagai indikasi perubahan, seperti kecenderungan dalam bisnis pakaian, berbagai outlet memasarkan produk dengan desain khusus dalam jumlah terbatas, untuk melayani pelanggan yang lebih memilih produk yang tidak diproduksi massal. Contoh lain, mini market yang bertebaran di wilayah pinggiran, menjadi pilihan konsumen karena kenyamanan berbelanja dibandingkan di warung-warung sekitar yang menjual produk sejenis. Konsumen juga menjadi lebih kritis memilih produk yang dianggap berkualitas. Produsen consumer goods berlomba memproduksi produk yang lebih natural dan sehat untuk memeroleh penjualan yang lebih baik. Hal ini juga berlaku pada produk-produk 'durables', seperti mobil, kulkas maupun televisi.

Perubahan perilaku konsumen dari pola pemasaran tradisional ke era digital menjadikan suatu pemahaman baru bahwa konsumen telah menjadi titik sentral dalam pengembangan strategi komunikasi pemasaran global. Konsumen memeroleh banyak informasi dari berbagai sumber sehingga mampuuntuk mengendalikan, mengontrol, dan menjadi penentu dalam aktivitas bisnis dan pemasaran.Berbeda dengan pemahaman konvensional yang mana produsen lebih bebas menentukan produk apa yang diperkirakan menjadi kebutuhan dan keinginan konsumen.

Di dalam buku Integrated Marketing Communications oleh Don E. Schultz, Stanley I. Tannenbaum, dan Robert F. Lauterborn, para penulis mengacu adanya empat perubahan utama yang berdampak pada perilaku konsumen, yakni perubahan dari verbal ke visual, fungsi illiteracy, fakta ke persepsi, dan berkembang biaknya media, yang menyebabkan terjadinya pengerucutan pasar (demassification of markets). Saat ini mayoritas perusahaan lebih banyak memanfaatkan visualisasi dalam kaitan merepresentasikan makna suatu produk ke dalam simbol, sebagai esensi dari pemasaran. Seperti kondisi pasar pada generasi milenial, konsumen tumbuh dan berkembang bersama ikon, tanda, atau simbol-simbol dalam top-ofmind mereka, sama halnya apabila kita berkomunikasi melalui media online.
Fungsi iliterasi tumbuh berkembang di masyarakat. Berbagai ikon, grafik, gambar, dan suara sebagai mekanisme bahwa berkomunikasi tidak lagi terbatas pada masyarakat literasi, tetapi berlaku untuk seluruh konsumen. Suatu tanda menggantikan kata dalam mengkomunikasikan suatu pesan. Dalam memasarkan produk, keputusan konsumen untuk membeli atau tidak, lebih didasari pada persepsi (brand image) dibandingkan fakta senyatanya. Fragmentasi media dalam berbagai bentuk, offline maupun online memaksa pemasar dan pasar terpecah-belah dalam berbagai ceruk, menjadikan integrasi berbagai elemen komunikasi dalam penyampaian pesan merupakan keharusan (Schultz et al, 1993:18-23).

Untuk memahami perilaku konsumen di kondisi banjir informasi seperti saat ini, peningkatan kemampuan pengelolaan database dalam skala besar (big data) yang berisi berbagai informasi tentang perilaku konsumen dan berbasis teknologi advances dalam kemampuan komputasi dan model-model analisis, mutlak diperlukan. Pemasar akan mampu melakukan analisis data demografi dan psikografi konsumen yang dikombinasikan dengan data tentang pembelian kategori produk dalam kurun periode tertentu, penggunaan media (media habits), dan penggunaan alat-alat promosi, yang mana data akan dapat dianalisis untuk menemukan pola-pola tertentu yang memungkinkan pemasar memprediksi bagaimana tanggapan konsumen atas berbagai aktivitas bauran pemasaran dan komunikasi, yang dikenal sebagai 'data mining' (Hoyer et al, 2018:33).

Pemahaman perilaku konsumen untuk memeroleh prediksi dalam pengembangan strategi bisnis dan pemasaran melalui pengelolaan data besar, dikenal sebagai Customer Relationship Management (CRM), yang mana 'CRM adalah suatu strategi yang menggunakan informasi, proses, teknologi, dan manusia untuk mengelola hubungan pelanggan (customer's relationship) dengan perusahaan (pemasaran, penjualan, pelayanan, dan dukungan) yang mencakup seluruh gaya hidup konsumen' (Kincaid, 2003:41). Adapun teknik 'data mining' tergantung pada pengembangan model-model yang mampu memprediksi perilaku konsumen yang didasari pada pola-pola dan asosiasi-asosiasi yang didapatkan komputer di dalam-yang biasa jumlah yang sangat banyak-pengelolaan data konsumen.

Penggunaan alat-alat teknologi informasi dalam memanfaatkan informasi konsumen yang tersedia-misalnya data terbaru tentang pembelian 
produk-memungkinkan kita untuk memeroleh pola-pola perilaku konsumen tertentu. Tentunya data mining sangat tergantung pada 'analisis mesin' dalam mencari pola-pola belanja konsumen yang mungkin tidak kita ketahui. Setelah menggunakan berbagai pola dalam membangun suatu model dan juga melakukan pengetesan data konsumen, kita akan dapat menyaring dan menerapkan pola tertentu yang terjadi pada pelanggan atau prospek, yang mana mungkin kita sebelumnya tidak memahami bagaimana perilaku konsumen sebenarnya (Kincaid, 2003:306). Sebagai hasil pemanfaatan data mining, luarannya memungkinkan kita untuk memeroleh acuan pengembangan rencana dari strategi sampai eksekusi dalam bisnis dan pemasaran. Maka, perubahan perilaku konsumen yang terjadi di era informasi, menjadi penting untuk dipahami dan dikelola sebagai acuan dasar dalam pengembangan strategi bisnis, pemasaran, dan komunikasi pemasaran pada pasar global.

\section{Pesan dan Merek Global}

Bermain di pasar global, merek sebagai cerminan inti pesan penjualan bagi suatu produk dan menjadi salah satu potensi elemen komunikasi dalam upaya mencapai kesuksesan, pada era digital masih tetap menjadi penentu dalam proses keputusan pembelian bagi konsumen. Untuk itu diperlukan adanya kejelian pemasar dalam membangun merek yang kuat, memilih langkah-langkah stratejik dalam mengkomunikasikan pesan penjualan melalui merek, dan diselaraskan dengan zaman terutama dalam pemanfaatan teknologi informasi, di samping pola pengembangan media konvensional secara terintegrasi, sehingga mampu memeroleh dampak yang optimal (Prayitno, 2020: 94).

Perlu dipahami bahwa keputusan konsumen dalam pembelian produk dipengaruhi oleh dimensi fungsi, penampilan phisik atau lingkungan, dan presentasi atau citra simbolik dari suatu produk yang akan menawarkan keuntungan bagi konsumen. Produk dapat diklasifikasikan ke dalam bentuk barang (goods) yang bersifat phisik (tangible), jasa (services) berbentuk tidak nyata (intangible), dan ide (ideas) sebagai suatu bentuk nilai (value) tertentu yang dipasarkan (Prayitno \& Harjanto, 2017:15). Ketiga jenis produk tersebut dari sudut pandang konsumen, produk lebih dipahami sebagai suatu citra produk atau merek (brand). Mengacu pada pemikiran Tom Duncan dalam bukunya Advertising \& IMC yang mendefinisikan bahwa merek adalah suatu persepsi hasil dari penga- laman dengan, dan informasi tentang suatu perusahaan atau suatu produk (Duncan, 2005:6), ma$\mathrm{ka}$, dalam upaya membentuk persepsi di benak konsumen, produk (barang, jasa, maupun ide) harus diubah ke dalam suatu bentuk intangible sebagai citra atau persepsi, yang dalam disiplin Komunikasi Pemasaran Terpadu dikenal sebagai strategi pengembangan pesan penjualan.

Konsep pengembangan pesan dapat dilakukan dari dua variabel, yakni apa nilai keuntungan yang melekat pada produk (product benefits) dan/atau dari sudut pandang apa yang menjadi kebutuhan dan keinginan konsumen (consumers' needs and wants). Salah satu dasar pengembangan pesan penjualan dalam upaya penciptaan inti pesan (core concept) atau dalam 'dunia periklanan' yang disebut sebagai penemuan 'the big idea' dari sudut pandang produk, dapat didasari pada pemikiran Chernatony dan McDonald dalam buku Creating Powerful Brands (1998) sebagai bagan The Chernatony and McDonald Chart. Konsep ini yang dikutip Chris Fill dan Tony Yeshin dalam buku Integrated Marketing Comunications, menyatakan bahwa citra merek (brand image) adalah impresi total yang diciptakan dalam benak konsumen oleh suatu merek dari seluruh asosiasi, fungsi, dan nonfungsi suatu produk atau merek (Chris \& Fill, 2001: 90-91).

Adapun bagan The Chernatony and McDonald Chart merinci suatu produk yang berlaku untuk barang, jasa, maupun ide. Produk terdiri dari dimensi tangible, yakni sebagai produk inti, yang meliputi unsur-unsur: fungsi, desain, fitur, kemanjuran, harga, dan kemasan yang dikenal sebagai elemen produk nyata (actual product). Dari dimensi intangible, dapat dikelompokkan dalam dimensi elemen produk tambahan (augmented product) dan citra produk (product image). Elemen produk tambahan terdiri dari unsur-unsur: pelayanan sebelum, selama, dan sesudah penjualan, delivery, ketersediaan, saran, bantuan sistem pembayaran, berbagai tambahan dan garansi. Sedangkan elemen citra produk meliputi unsur-unsur: persepsi pada kualitas, persepsi pada nilai, pengaruh pengguna lain, reputasi, citra perusahaan, nama merek, dan organisasi. Dari berbagai unsur yang ada pada dimensi elemen tangible maupun intangible-tentunya tidak semua unsur-dapat dikembangkan menjadi inti pesan yang memberikan nilai persepsi khusus bagi suatu produk. Sebaliknya, apabila pengembangan inti pesan 'berangkat' dari kebutuhan dan keinginan konsumen, tentunya harus didasari data hasil penelitian ten- 
tang keterikatan antara konsumen dengan kategori produk tertentu.

Pada dasarnya proses komunikasi penyampaian pesan merek yang telah tercipta agar menjadi persepsi atau berada di benak konsumen, memang tidak bisa berjalan cepat. Demikian juga dalam membangun citra merek global sering berjalan lamban, mengingat adanya berbagai perbedaan di pasar global, yakni: adanya perbedaan tahapan daur hidup produk (product life cycle) dan perbedaan tingkat pemahaman tentang apa konsep suatu merek dan tingkat emosional yang ada di antara budaya yang berbeda. Halangan lain adalah mungkin organisasi perusahaan masih menyandarkan pada sistem dan budaya perusahaan, tidak atau belum melakukan pendekatan global yang terintegrasi (Schultz \& Kitchen, 2000:160). Maka, dalam penyebaran pesan penjualan pada pendekatan global, diperlukan juga pemahaman tentang media global, khususnya pola-pola penetrasi media online.

\section{Media Penetrasi Global}

Pada era konvensional sebelum ditemukannya internet, kita hanya mengenal adanya pola komunikasi melalui media interpersonal (interpersonal media) dan media massa (mass media). Pada era teknologi informasi, muncul pola komunikasi baru yang selanjutnya dikenal sebagai bentuk komunikasi interaktif (interactive communication), yang pada intinya segala pola komunikasi yang menggunakan internet dan berbagai peralatan digital terkait lainnya-hardware dan software-yang dikenal sebagai pola komunikasi melalui media interaktif atau media digital (interactive/digital media).

Komunikasi interpersonal merupakan bentuk awal pemahaman mengenai media komunikasi, yang menurut Bochner (1978) komunikasi interpersonal adalah pengiriman pesan oleh seseorang dan pesan diterima oleh orang lain atau sekelompok kecil orang, dengan beberapa dampak dan beberapa peluang untuk memeroleh tanggapan (feedback) segera. Definisi ini dikenal sebagai komunikasi interpersonal yang berbasis pada komponen komunikasi (componential). Adapun, Cappella (1987) menyatakan bahwa komunikasi interpersonal merupakan komunikasi yang berada antara dua orang yang memunyai suatu kejelasan hubungan yang mapan, yang dikenal sebagai keterkaitan (relational). Sedangkan Miller (1978) mengatakan bahwa suatu proses dari komunikasi interpersonal berakhir pada satu titik ekstrem bagi seseorang atau tercapainya keintiman komunikasi dari satu personal dengan personal lainnya. Definisi dari Miller ini dikenal sebagai komunikasi pengembangan (developmental).

Dari ketiga definisi tersebut, terangkum pada pemikiran Josepth A. DeVito dalam buku The Interpersonal Communication Book, bahwa komunikasi interpersonal adalah bentuk komunikasi tatap muka antara dua orang atau lebih (kelompok) dalam penyampaian pesan timbal-balik yang dapat berkembang sehingga tercapai satu pemahaman bersama (DeVito, 1989:96-97).

Adapun tentang pemahaman media massa, seperti tersebut dalam buku The Media of Mass Communication, John Vivian mendefinisikan bahwa komunikasi massa adalah bentuk komunikasi sebagai suatu proses yang menggunakan media massa dalampenyampaian pesan pada khalayak yang luas yang bertujuan menginformasikan, menghibur, atau memersuasi. Maka, media massa memungkinkan untuk mencapai ratusan bahkan jutaan khalayak, yang mana pesan disalurkan melalui berbagai saluran media massa, seperti televisi, radio (media siar), dan media cetak seperti surat-kabar dan majalah (Vivian, 1993:20). Di samping itu, dampak pesan yang disampaikan melalui media massa memunyai keterbatasan dalam memeroleh 'umpan-balik' dan dalam jangka waktu yang relatif lama.

Berbeda dengan bentuk media komunikasi konvensional, misalnya periklanan, yang memanfaatkan media massa untuk penyampaian pesan yang bersifat searah dari komunikator kepada penerima pesan, sedangkan pola komunikasi interaktif atau digital, di era teknologi informasi dikenal adanya bentuk media baru (new media) yang memanfaatkan internet sebagai media interaktif atau media digital. Ditinjau dari dimensi substansi, pola penyampaian pesan dalam komunikasi interaktif lebih bersifat dialog, yang mana media baru tersebut memungkinkan berbagai bentuk pola komunikasi, bisa searah, timbal-balik, bahkan dalam bentuk diskusi yang memusat. Peranan komunikator dan komunikan bisa berganti peran, pesan berupa gambar, audio, video, atau tulisan bisa berkembang, dan fungsi peran sebagai pesan informatif, persuasif, bahkan sampai kursif untuk mendorong terjadinya tindakan segera, dapat terjadi dalam waktu yang bersamaan (real-time) dan menyebar tanpa batas (borderless) dalam jaringan yang dapat mencakup seluruh dunia.

Pada dasarnya, media interaktif memunyai sifat bawaan sebagai bentuk pola komunikasi antar- 
persona (interpersonal communication) dan juga komunikasi massa (mass communication), ditambah dengan sifat-sifat tersendiri akibat adanya teknologi informasi, terutama internet, sehingga muncul species media baru yang dikenal sebagai media interaktif/digital.

Saat ini dan di masa mendatang peranan media interaktif menjadi tulang punggung dalam bisnis dan pemasaran di era global. George E. Belch dan Michael A. Belch dalam buku Advertising and Promotion: An Integrated Marketing Communications Perspective, menyatakan bahwa media interaktif memungkinkan aliran informasi timbalbalik dengan cara para pengguna dapat berpartisiasi di dalam dan memodifikasi bentuk dan isi pesan informasi yang diterima dalam waktu yang bersamaan. Adapun bentuk media internet/interaktif yang digunakan dalam pemasaran (interactive marketing), dapat berupa CD-ROMs, kiosks, televisi interaktif, media sosial, dan media internet lainnya, khususnya dalam pemanfaatan melalui komponen yang dikenal sebagai World Wide Web (Belch \& Belch, 2012:21-22).

Sedangkan, Damian Rian dalam buku Understanding Digital Marketing mengemukakan bahwa dalam era digital kita membutuhkan suatu strategi pemasaran yang berbasis digital. Mengapa demikian, karena tanpa pemanfaatan komunikasi digital kita akan kehilangan peluang dan bisnis kita akan lenyap. Apapun bisnis kita, konsumen saat ini akan menggunakan media online dalam melakukan pencarian produk atau merek, mengevaluasi, menetapkan pilihan,dan mengkonsumsi produk pemasar. Konsumen melakukan keputusan pembelian didasari pada persepsi kualitas dari seluruh pengalaman online, tidak seperti dalam pola konvensional yang mana produsen dan konsumen menggunakan pola 'bricks-and-mortar', yakni pola tradisional dalam 'bisnis jalanan' yang menawarkan produk dan jasa melalui komunikasi interpersonal. Masa kini konsumen beralih ke belanja online (Rian, 2014:21-23).

Secara sederhana, seperti tersebut dalam Dictionary of Marketing Term (2000), bahwa internet marketing adalah proses membangun dan memelihara hubungan dengan pelanggan (customer relationships)-sebagai tujuan akhir dari bisnis dan pemasaran-melalui aktivitas online dalam memfasilitasi pertukaran ide, barang, dan jasa yang memuaskan tujuan kedua belah pihak, produsen dan konsumen.

Saat ini kerancuan gangguan komunikasi terjadi akibat dari adanya dampak banjir informasi yang sangat besar dibanding era terdahulu sebelum adanya internet. Sebagai ilustrasi, konsumen mudah mencari dan mendapatkan informasi hampir tak terbatas tentang produk dari 'ketukan jarijari' mereka. Persaingan semakin tajam di semua lini, lebih banyak lagi produk yang kompetitif, saluran distribusi yang semakin beragam, dan lebih banyak pertimbangan yang dapat dilakukan konsumen dalam proses mengkonsumsi produk. Paradigma lama tentang pemasaran yang mendorong pesan penjualan sebagai pesan tunggal melalui saluran media interpersonal dan/atau media massa dalam ruang lingkup yang relatif lebih sederhana agar pesan produk dapat didengar, dibaca, atau dilihat oleh konsumen, dan diharapkan akan berdampak pada terjadinya penjualan, telah berganti arah.

Di era informasi telah tercipta nuansa baru, muncul suatu saluran media interaktif yang berdampak langsung dan semakin kompleks sebagai media digital. Paradigma baru dalam pemasaran, bahwa pesan pemasaran harus disampaikan secara terpecah dan perlu kreativitas dan sinergitas dalam pemanfaatan media digital guna mencapai khalayak sasaran atau konsumen pada saat yang tepat. Eric Greenberg dan Alexander Kates dalam buku Strategic Digital Maketing menggambarkan adanya 'lensa cekung digital' yang membiaskan pesan menjadi terpecah-belah dalam berbagai bentuk media saluran (lihat Bagan: 1). Walaupun inti pesan penjualan (merek) yang akan dipasarkan adalah pesan tunggal, tetapi melalui media digital pesan wajib dipecah-belah disesuaikan sesuai saluran media digital yang semakin terjadi fragmentasi.

Bagaimana pun, bagi pemasar pesan penjualan tidak mudah disalurkan melalui berbagai media interaktif yang kompleks, tidak seperti ketika 'kemudahan' yang ada pada penyaluran pesan melalui media massa. Pesan perlu dikembangkan lebih lanjut dalam bentuk eksekusi pesan yang disesuaikan dengan kelompok penerima (group of peers) yang tersekat-sekat (niche market) dalam saluran media yang menjadi kebiasaan masingmasing kelompok. Pada dasarnya, media interaktif yang utama sebagai dasar penyampaian pesan penjualan adalah pemanfaatan 'World Wide Web' atau lebih dikenal sebagai Website. Selanjutnya terjadi proliferasi media digital dalam bermacam bentuk, seperti: Search Marketing, Mobile Marketing, Social Media, Video Marketing, Digital Storefronts, Gamified Environments, dan masih akan berkembang lebih banyak lagi. Maka, pemasar ju- 
ga harus tetap menjaga agar pesan yang sudah 'terpecah-belah' dalam media digital yang dimanfaatkan tersebut dapat diterima sebagai pesan yang bermakna tunggal (inti pesan) oleh masingmasing kelompok sasaran (Greenberg \& Kates, 2014:4-7)

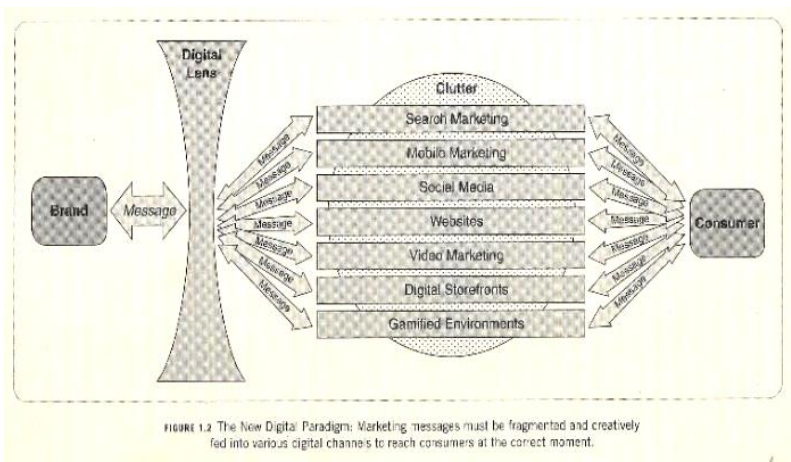

Bagan 1. Paradigma Baru Media Digital Sumber: Green Berg \& Kates, 2014

Pada akhirnya, paradigma baru media interaktif/digital juga menumbuhkan suatu dunia yang penuh kejujuran, akuntabilitas, dan keterbukaan yang total dari suatu merek atau produk. Kisah sukses perusahaan atau produk juga akan lebih cepat berkembang dan meluas dibanding era sebelumnya. Kejelian pemasar dan adanya media penyebaran pesan merek melalui berbagai saluran, merupakan tantangan bagi pemasar untuk menangkap peluang bisnis yang mungkin tidak pernah terjadi di era konvensional. Pada era pasar global, pemanfaatan media interaktif sebagai saluran penyampaian pesan menjadi suatu keharusan, di samping tetap melakukan integrasi dalam berkomunikasi melalui media digital dan media konvensional untuk memeroleh sinergi yang optimal.

\section{METODE}

Metode dalam penelitian ini adalah literatur review yang digunakan untuk meninjau berbagai buku tentang Integrated Marketing Communication, Brand, dan Customer guna menjelaskan "Komunikasi Pemasaran Global: Tantangan di Era Digital" dengan cara mengeksplorasi hal-hal yang belum pernah diteliti (Denney \& Tewksbury, 2012). Penelitian ini dianggap telah menggunakan primary source dengan mengakses buku-buku yang "trustable" yang merupakan syarat sebuah literature review (Bolderston 2008). Dengan demikian, literature review di dalam penelitian ini dilakukan dengan cara mengumpulkan, memahami, menganalisis, mensintesis dan mengevaluasi berbagai buku, yang dilakukan secara bertahap dan berulang-ulang, dibandingkan dan disintesiskan secara terus-menerus, dalam rangka menjawab "Komunikasi Pemasaran Global: Tantangan di Era Digital" (Estaswara, 2021).

\section{HASIL DAN PEMBASAHAN}

\section{Komunikasi Pemasaran di Era Global}

Kata Pengantar dalam buku The Future of Marketing: Practical Strategies for Marketers in the PostInternet Age, yang ditulis oleh Cor Molenaar menyatakan bahwa manusia mungkin tidak berubah, tetapi teknologi melakukannya. Selanjutnya, teknologi mendorong organisasi untuk berubah dan teknologi mengubah hubungan manusia dan organisasi. Orang tidak lagi pergi bekerja, pekerjaan yang akan datang pada orang. Kita sudah lama tidak lagi pergi berbelanja, belanja dapat dilakukan dari rumah. Tiba-tiba rumah dan lingkungan kembali menjadi penting. Maka, kini kita dapat mengorganisasikan bisnis dan masalah-masalah pribadi lainnya yang dilakukan dari rumah. Sudah tidak ada batas yang jelas antara rumah dan tempat kerja, antara belajar dan pekerjaan, antara bisnis dan kehidupan pribadi. Konsumen saat ini menginginkan pemasar untuk mengenal dan mengingat mereka, memahami apa yang menjadi kebutuhan dan keinginannya, dan mengupayakan produk yang dapat memenuhi apa yang dibutuhkan dan diinginkan konsumen (Molenaar, 2002:xxii-xxv).

Ilustrasi di atas sekedar memberikan gambaran bahwa perubahan besar telah terjadi garagara internet. Di industri komunikasi pemasaran khususnya, berbagai perubahan perlu kita cermati agar mampu mengantisipasi perubahan yang terjadi dari pola-pola komunikasi konvensional yang dapat diterapkan di era teknologi informasi, supaya dapat 'berlayar dengan nyaman' di pasar global. Revolusi strategi komunikasi pemasaran diawal periode 1990-an telah menciptakan Integrated Marketing Communications (IMC) sebagai suatu konsep antisipasi strategi-strategi komunikasi dan pemasaran konvensional, yang dirasakan sudah tidak berdampak optimal. Penerapan prinsip-prinsip dasar IMC pada pasar global, memungkinkan pemasar memeroleh 'peta jalan' untuk mencapai kesuksesan bisnis dan pemasaran pada dinamika pasar milinium baru abad ke-21 ini.

Adapun delapan prinsip dasar dalam konsep IMC, meliputi: (1) Menjadi organisasi yang berorientasi pada konsumen, (2) dalam perencanaan bisnis atau pemasaran menggunakan pendekatan 
outside-in, (3) fokus pada pengalaman konsumen terhadap produk dan perusahaan, (4) penyelarasan antara tujuan konsumen dengan tujuan organisasi/perusahaan, (5) menentukan tujuan perilaku konsumen, (6) mengelola konsumen sebagai aset, (7) melakukan perampingan pada kegiatan yang fungsional, dan (8) mengintegrasikan kegiatan komunikasi pemasaran (Schultz \& Schultz, 2003:49-67).

Agar dapat menciptakan sistem komunikasi dan program komunikasi pemasaran di pasar global, menurut Don E. Schultz dan Philip J. Kitchen terdapat empat elemen utama yang menjadi dasar dalam menghadapi pasar global, yang disebut sebagai 'Global Building Blocks', yakni: digitalisasi (digitalization), teknologi informasi (information technology), kekayaan intelektual (intellectual property), dan sistem komunikasi (communication systems). Digitalisasi adalah kemampuan untuk mengubah hampir seluruh tipe pengetahuan, informasi, dan material ke dalam bentuk digital (1 dan 0) yang dapat 'memanipulasi' data melalui komputer dan sistem elektronik lainnya sehingga mampu mengubah dunia. Sedangkan teknologi informasi bermakna bahwa seluruh alat, teknik, dan kemampuan yang memungkinkan pengetahuan, data, dan pengalaman dapat ditransfer cepat dan mudah antar institusi atau individu ke seluruh dunia.

Pemahaman konvensional atas kekayaan negara, organisasi bisnis, dan individu dinilai dari dan berdasarkan aset nyata (tangible assets), seperti dalam bentuk benda material, tanah, pabrik, bangunan, termasuk dana tunai, dan logam mulia. Di era digitalisasi muncul kekayaan baru berupa intangible assets, yakni pengetahuan, pengalaman, pemahaman, dan kemampuan, sebagai bentuk intellectual property. Adapun sistem komunikasi merupakan bagian dari digitalisasi dan teknologi informasi untuk dipertimbangkan sebagai hal yang kritis dalam pemasaran dan komunikasi pemasaran global di masa depan. Historis, sistem komunikasi bersifat linier, dikembangkan, diorganisasikan, dan didistribusikan dari sumber tunggal ke penerima pesan secara massal. Pada era teknologi informasi, sistem komunikasi berubah dramatis menjadi interaktif (interactive communication). Terjadi dialog antara sumber dan penerima pesan yang dapat berganti peran, pesan bisa berkembang 'liar', dampak langsung, real time, dan tanpa batasan tempat dan waktu (Schultz \& Kitchen, 2000:3-5).

Dari dimensi lain, pada era global terjadi tran- sisi dalam pola komunikasi antara produsen atau pemasar dengan pasar sasaran, yang dapat dipahami dalam tahapan pergeseran yang selaras dengan perkembangan zaman. Schultz dan Kitchen menyebutkan ada tiga tahap pergeseran pola komunikasi dalam bisnis dan pemasaran, yang meliputi: pasar yang digerakkan oleh produsen (the Manufacturer-Driven Marketplace), pasar yang digerakkan oleh perantara (the DistributionDriven Marketplace), dan pasar di era interaktif (the Interactive Marketplace). Dalam sejarah pemasaran-bahkan mungkin juga masih terjadi pada saat ini-pada tahap pola konvensional, produsen yang memegang kendali pasar. Produk apa yang harus ditawarkan, apa seharusnya produk yang dapat dibeli konsumen, bagaimana distribusi produk, berapa harga yang ditetapkan, bagaimana cara promosi/komunikasi yang diterapkan, dan pengelolaan informasi pasar,produsen yang menentukan.

Produsen mendorong produknya ke pasar (selling-in) dan konsumen mencari dan membeli produk sesuai dengan kebutuhannya yang tersedia di pasar (selling-out). Pola komunikasi pemasaran yang terjadi adalah searah, baik secara langsung pada konsumen dan/atau distributor dalam komunikasi tatap muka (interpersonal communication) atau menggunakan media massa (mass communication). Konsumen menjadi 'sasaran tembak' melalui elemen-elemen promosi seperti advertising, public relations, sales promotion, direct marketing, dan/atau personal selling. Tahap ini disebut sebagai the Manufacturer-Driven Marketplace.

Perkembangan berikutnya adalah perantara atau distributor yang mengambil alih peranan produsen, yang mana ditandai dengan munculnya berbagai pusat perbelanjaan, wholesalers, jaringan pengecer, maupun minimarket. Dalam fase the Distribution-Driven Marketplace kendali pasar berada di tangan distributors. Mereka yang memilih produk apa yang akan ditawarkan ke konsumen, produk-produk mana yang layak dipromosikan, menentukan penetapan harga pasar, dan strategistrategi komunikasi untuk menarik konsumen agar berbelanja, perantara yang memegang kendali pasar. Adapun proses implementasi pemasaran seperti pola distribusi, pola komunikasi, dan peranan konsumen tetap sama seperti pada fase the $\mathrm{Ma}$ nufacturer-Driven Marketplace. Khususnya kendali komunikasi dan informasi untuk menggerakkan pasar berpindah dari tangan produsen ke distributor. 
Perubahan drastis terjadi di era teknologi informasi yang memorak-porandakan pola strategi pemasaran dan sistem komunikasi pemasaran yang sudah mapan. Pada fase the Interactive Marketplace, kekuasaan dan kendali berpindah dari pelaku bisnis dan pemasaran ke tangan konsumen. Dalam perencanaan strategis (strategic planning), produsen atau pemasar sudah saatnya mengubah pandangan dari inside-out menjadi outside-in planning, yang bermakna dalam perencanaan strategi bisnis, pemasaran, dan komunikasi pemasaran wajib didasari pada pemahaman menyeluruh tentang perilaku konsumen sebagai dasar utama dalam pengembangan strategi-strategi penguasaan pasar. Patut dipahami, pada era ini, kendali informasi berada di tangan konsumen, dan pola komunikasi berubah total dari searah (monolog) menjadi interaktif (dialog) (Lihat Bagan 2).

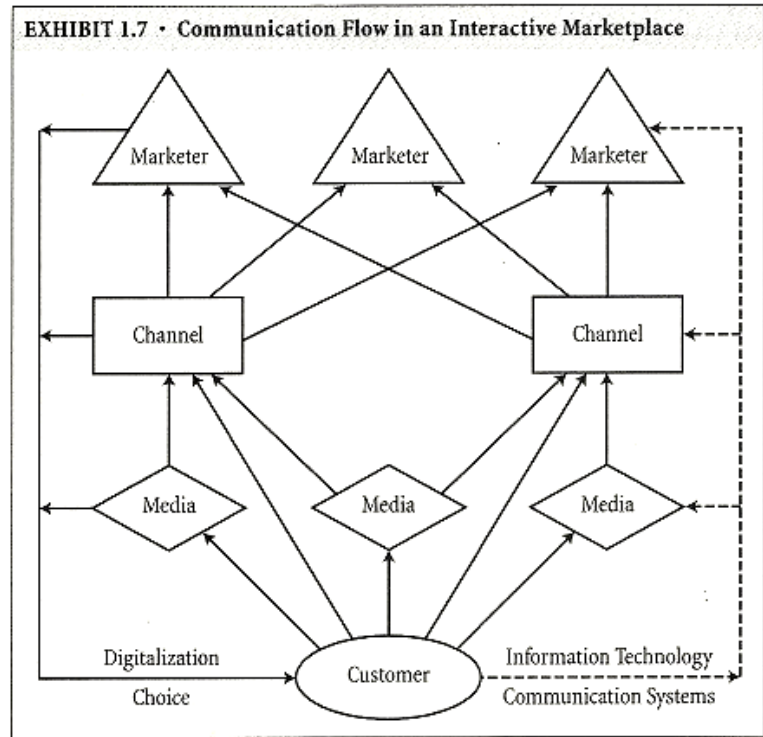

Bagan 2. Alur Komunikasi dalam Era Pasar Interaktif Sumber: Schultz \& Kitchen, 2000

Berbasis pada arus komunikasi di era interaktif, bagaimana seharusnya melakukan aktivitas pada organisasi pemasaran global? Christopher Bartlett dan Sumantra Ghoshal (1988) dalam buku Managing Across Borders, mengidentifikasi ada tiga kekuatan utama yang dapat menggerakkan strategi perusahaan atau organisasi dalam menghadapi kondisi lintas batas, melakukan perlindungan perusahaan, dan pemahaman terhadap budaya setempat. Perusahaan-perusahaan seperti ini yang disebut sebagai organisasi transnasional. Adapun ketiga pendekatan tersebut meliputi: (1) Integrasi Global (Global Integration), (2) Tanggung
Jawab pada Kondisi Lingkungan Nasional (Responsiveness to National Environments), dan (3) Warisan Budaya Administrasi (Adminstrative Heritage).

'Integrasi Global' bermakna bahwa pada dekade yang baru lalu, kita berada dalam suatu era di mana telah terbentuk perubahan perlindungan diri secara global, tumbuhnya batasan regional, perkembangan teknologi masa kini yang terus berubah, struktur ekonomi yang tergantung pada industri, dan dinamika persaingan yang diformulasi ulang dalam 'aturan permainan' baru. Pada situasi seperti ini, maka perusahaan harus mampu melakukan aktivitas yang terintegrasi dan terkoordinasi yang meliputi lintas batas nasional. Adapun 'Tanggung Jawab pada Lingkungan Nasional', bahwa sebagai perusahaan internasional tentunya harus memahami adanya kekuatan lain, yang mana diperlukan sensitivitas dan cepat tanggap pemasar pada kondisi lingkungan nasional pasar sasaran. Pada dasarnya konsumen berbeda di setiap negara, infrastruktur juga berbeda, pola persaingan, dan negara penerima umumnya mensyaratkan perusahaan agar mengakomodasi kepentingan yang berbeda-beda di setiap negara.

Adapun makna 'Warisan Administrasi' meliputi banyak aspek dari suatu kondisi perusahaan di masa lalu, yang mana perusahaan memiliki budaya dari negara asal, sejarah, pengaruh tertentu dari individual, dan semua itu secara kolektif merupakan suatu warisan administrasi perusahaan. Apabila aktivitas perusahaan lebih bersandar pada pendekatan warisan administrasi, penting untuk dipahami bahwa terdapat dua alasan utama, yakni: pertama, suatu perusahaan harus mengenal apa jenis kekuatan warisan adminstrasi dan bagaimana melindunginya. Kedua, pada waktu yang bersamaan apabila menerapkan pendekatan warisan administrasi, maka dapat juga menjadi halangan terbesar bagi perusahaan untuk berubah (lihat Bagan 3).

Untuk memasuki pasar global-dalam makna pasar di negara mana saja di dunia-yang dikaitkan dengan kondisi perusahaan, ketiga strategi pendekatan tersebut dapat diterapkan, tergantung pada situasi pasar setempat (kondisi eksternal) dan kondisi perusahaan (kondisi internal). Apabila perusahaan menerapkan sebagai international companies, maka pengembangan strategi pendekatan lebih berdasarkan Adminstrative Heritage, yakni lebih didominasi oleh 'kebiasaan' aktivitas perusahaan di negeri asal untuk diterapkan di pasar global.

Sedangkan perusahaan yang mengembangkan 


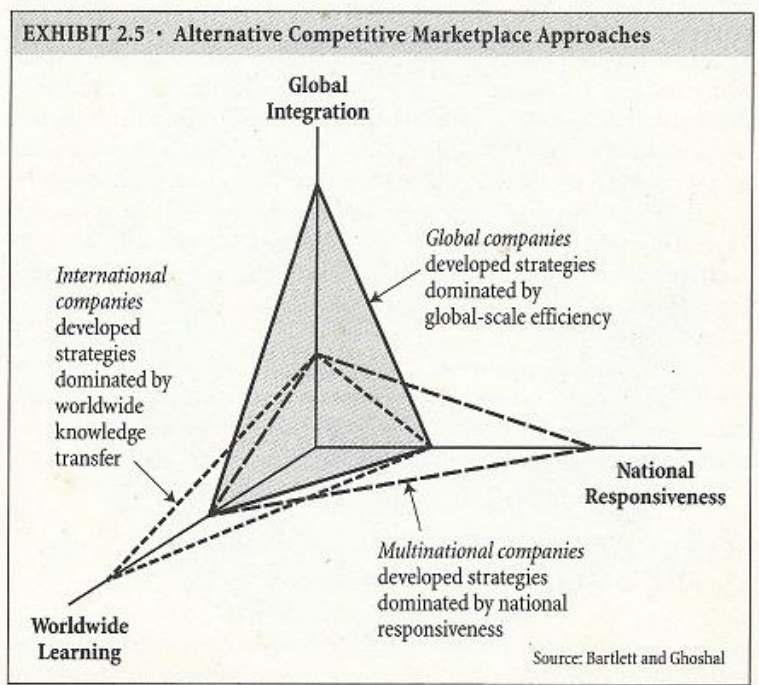

Bagan 3. Pendekatan Alternatif Pasar Global Sumber: Bartlett \& Ghoshal, 1988

strategi lebih didasari pertimbangan kondisi dan situasi negara setempat, maka lebih berorientasi pada Responsiveness to National Environments. Apabila strategi perusahaan lebih didominasi oleh pertimbangan skala efisiensi global, maka pendekatan global yang terintegrasi (Global Integration) sebagai pilihan terbaik dalam menghadapi kondisi dan situasi di era teknologi informasi saat ini dan di masa mendatang.

Sekedar contoh, restoran cepat saji sejenis Kentucky Fried Chiken (KFC), perusahaan induknya 'hanya' menjual lisensi merek (intellectual property), tidak perlu investasi di wilayah negara pasar global, gaji manager dan staf menjadi tanggungjawab penerima waralaba (franchisee) setempat, bahan-bahan dasar produksi diambil dari lingkungan sekitar, menu saji disesuaikan selera pasar (global) setempat, dan hal-hal teknis lainnya yang disesuaikan kondisi negara sasaran. Di mana, yang utama adalah bagaimana perusahaan induk tetap dapat mengontrol standar kualitas produk dan menjaga nilai merek (brand value), dalam pemahaman melakukan aktivitas integrasi global.

Berbasis pemahaman tentang delapan prinsip dasar dalam perencanaan strategis Integrated Marketing Communications, empat pilar 'The Global Building Blocks' sebagai elemen utama yang menjadi dasar dalam menghadapi pasar global, alur pola sistem komunikasi di era teknologi informasi, tiga arahan implementasi alternatif pendekatan dalam penetrasi pada pasar global, dan pemahaman data tentang kondisi dan situasi terkait (data primer maupun sekunder), maka perencanaan komunikasi pemasaran global terpadu (Integrated Global Marketing Communications/IGMC)

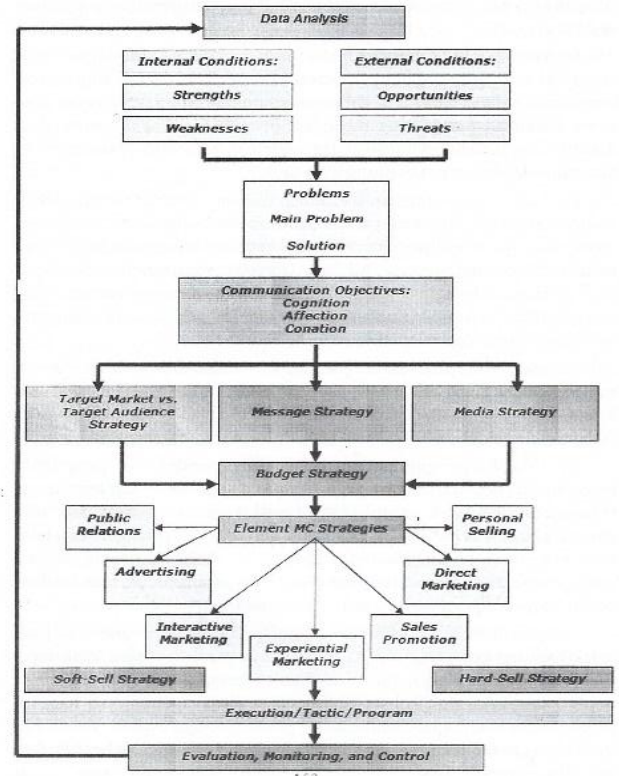

Bagan 4. Proses Perencanaan Komunikasi Pemasaran Global Terpadu

Sumber: Prayitno \& Harjanto, 2017

dapat diterapkan. Salah satu acuan dalam pengelolaan rencana IGMC, seperti yang dikemukakan Sunarto Prayitno dan Rudy Harjanto dalam buku Manajemen Komunikasi Pemasaran Terpadu: Bisnis, Pemasaran, dan Komunikasi Pemasaran, Seri \#1, terdiri dari lima tahapan, meliputi: latar belakang, tujuan, strategi, taktik, dan evaluasi (Prayitno \& Harjanto, 2017:130-143). Proses pengembangan rencana IGMC secara rinci dalam alur tahap perencanaan, dapat dilihat pada Bagan 4.

Dalam tahapan Latar Belakang-sesuai prinsip dasar 'outside-in approach'-adalah melakukan analisis tentang data eksternal, yang meliputi kondisi makro, perilaku konsumen atau khalayak/pasar sasaran, dan situasi persaingan; dan juga data internal yang meliputi kondisi organisasi/perusahaan dan produk, elemen produk seperti harga/ nilai, distribusi, promosi, physical evidence, people, dan process. Dari data eksternal dan internal dilakukan analisis sederhana memanfaatkan analisis Strengths, Weaknesses, Opportunities, dan Threaths (SWOT analysis). Pada tahap ini digunakan untuk menemukan berbagai masalah dalam bisnis dan pemasaran, baik dari kondisi eksternal maupun internal. Dari berbagai masalah yang ditemukan, disusun berdasarkan skala prioritas. Dari masalahprioritas, dicari solusi untuk mengatasinya dan juga merupakan acuan dalam penentuan 'inti pesan'. Singkat kata, dari masalah bisnis dan pemasaran, dicarikan solusi sebagai dasar penemuan inti pesan (core concept) yang akan mewarnai seluruh aktivitas komunikasi pemasaran. 
Pada tahap penentuan tujuan komunikasi, berbasis 'inti pesan' yang akan disampaikan maka dapat menentukan tujuan komunikasi apa yang harus diterapkan. Apakah tujuan kognisi yang akan memberikan informasi dan pemahaman berdasarkan logika, atau untuk tujuan afeksi, yakni 'menyerang' hati atau perasaan agar penerima pesan menjadi suka, memilih, dan yakin akan pesan yang disampaikan, atau langsung pada konasi (behavior) agar khalayak sasaran melakukan tindakan segera tanpa banyak pertimbangan. Dalam penentuan tujuan komunikasi tentunya tidak ketiganya dipilih sekaligus dalam satu periode program, harus dipilih tujuan mana yang paling efektif sesuai solusi yang ditetapkan.

Untuk mencapai tujuan komunikasi yang telah ditetapkan, dijabarkan dalam lima strategi dasar dalam IGMC, meliputi: (1) strategi penentuan khalayak sasaran (target audience) yang dikaitkan dengan pasar sasaran (target market); (2) pemilihan strategi pesan yang dikembangkan dari inti pesan ke dalam pola pendekatan (approach) dan daya tarik (appeal), dan bentuk-bentuk eksekusi (execution) pesan yang disesuaikan dengan pilihan media; (3) strategi pemilihan media, baik media interpersonal, massa, maupun interaktif; (4) strategi anggaran dalam makna penentuan anggaran integrasi elemen komunikasi pemasaran yang paling optimal, efektivitas sekaligus efisien dan mampu menggerakkan 'income-flow' sebagai dampak program komunikasi yang diaplikasikan (dalam konsep IMC dikenal sebagai Return on Customer Investment/ROCl); dan (5) strategi bauran elemen-elemen promosi atau komunikasi pemasaran yang terintegrasi, yang menetapkan elemen promosi yang dipilih sebagai elemen utama dan apa saja elemen-elemen pendukungnya.

Berbagai bentuk elemen promosi dapat diklasifikasikan dalam strategi hard-sell (yang langsung untuk menggerakkan 'penjualan') dan soft-sell sebagai bentuk strategi tidak langsung yang juga akan berdampak pada penjualan (action). Tentunya pemilihan pendekatan soft-sell atau hard-sell tergantung pada tujuan komunikasi yang ditetapkan, apakah lebih ke kognisi dan afeksi yang cenderung memilih strategi soff-sell sebagai elemen komunikasi pemasaran yang utama,atau ke konasi atau perilaku yang mengutamakan strategi hardsell.

Adapun tahapan taktik sebagai penjabaran rinci strategi dalam program IGMC, yang merupakan bentuk eksekusi strategi yang telah ditetapkan dan menjadi pedoman pelaksanaan. Kata lain, program merupakan penjabaran konsep-konsep strategi ke dalam bentuk kongkrit sebagai pedoman yang dapat diimplementasikan. Tahapan akhir adalah tahap perencanaan evaluasi, monitoring, dan kontrol pada penerapan program. Hasil temuannya akan menjadi data masukan untuk memahami dampak program yang telah dilaksanakan dan juga sebagai data dalam perencanaan IGMC berikutnya. Bentuk sistem perputaran program secara berkesinambungan (closed-loop) seperti ini, harus dilakukan terus-menerus sampai tercapainya tujuan akhir bisnis dan pemasaran, yakni dalam makna pencapaian hubungan yang saling menguntungkan antara produsen dan konsumen dalam jangka panjang, yang disebut sebagai terciptanya brand relationships.

\section{SIMPULAN}

Integrated Marketing Communications (IMC) merupakan suatu konsep bisnis, pemasaran, dan komunikasi pemasaran yang merupakan hasil temuan dinamika perubahan zaman dari era konvensional ke era digital, sebagai paradigma baru konsep, strategi, taktik, dan implementasi yang diyakini mampu mengantisipasi situasi dan kondisi perubahan yang terjadi pada abad ke-21 di masa kini dan mendatang. Setelah ditemukannya komputer, khususnya internet, kondisi pasar lokal (traditional marketplace) berubah dramatis menjadikan dunia menjadi suatu bentuk baru sebagai pasar global (global marketplace).

Strategi dan taktik konvensional yang semula mampu dihandalkan untuk mencapai kesuksesan bisnis di masa lalu, pada era teknologi informasi dirasakan menjadi tumpul. Evolusi IMC menggeser pola-pola konvensional pada tahapan pemikiran baru yang meliputi: (1) koordinasi taktik elemen komunikasi pemasaran, (2) mendefinisikan ulang cakupan makna komunikasi pemasaran, (3) pengaplikasian teknologi informasi, dan (4) menerapkan strategi integrasi dalam pengelolaan bisnis (keuangan) dan komunikasi pemasaran.

Secara mendasar akibat adanya internet perubahan perilaku konsumen ikut andil dalam pendekatan strategi bisnis dan pemasaran. Semula perencanaan yang biasanya berbasis pada kondisi internal perusahaan (inside-out planning), pada era pasar global selayaknya pendekatan berbalik diawali dari pemahaman menyeluruh tentang perilaku konsumen sebagaiacuan dalam perencanaan stratejik (outside-in planning). Dalam penetapan segmentasi pasar, selain berfokus pada klasifikasi demografi, pemahaman psikografi konsumen 
akan lebih bermakna dalam pendekatan pasar.

Pada pasar modern dewasa ini konsumen cenderung menjadi individual, orientasi pada kualitas, mengutamakan kenyamanan, dan selektif dalam memilih produk yang alami dan sehat. Peranan teknologi informasi juga menjadi penting dalam pengelolaan konsumen. Di samping konsumen dalam berkomunikasi lebih mengutamakan penggunaan media online, produsen juga dihadapkan pada konsumen global dalam jumlah yang besar. Pemanfaatan teknologi informasi menjadi mutlak dalam pengelolaan data perilaku konsumen seperti pemanfaatan Customer Relationship Management (CRM) untuk memeroleh strategi yang optimal.

Pesan merupakan jiwa dalam suatu strategi komunikasi pemasaran. Produk, baik berupa barang, jasa, maupun ide pada pasar global lebih dipahami sebagai suatu persepsi yang ada di benak konsumen, yang dikenal sebagai merek. Pengembangan pesan penjualan, dapat didasari dari apa yang dapat menjadi kelebihan produk, dan dapat juga dikembangkan dari apa yang menjadi kebutuhan dan keinginan konsumen. Produk terdiri dari dimensi yang meliputi produk inti dan produk nyata sebagai dimensi tangible, dan produk tambahan dan produk citra sebagai dimensi intangible. Dari unsur-unsur yang ada pada dua dimensi tersebut yang dirasakan sebagai kelebihan produk, dapat dikembangkan menjadi inti pesan penjualan. Sebaliknya, apabila pesan penjualan dikembangkan dari kebutuhan dan keinginan konsumen, harus dilakukan penelitian tentang pemahaman dan harapan konsumen terhadap suatu produk kategori.

Pada kondisi pasar tradisional sebelum ditemukannya internet, penyampaian pesan penjualan hanya disalurkan melalui media interpersonal atau tatap muka secara langsung dan media massa yang menggunakan media perantara seperti radio, televisi, suratkabar, majalah, dan media massa lainnya yang dapat mencapai khalayak sasaran dalam jumlah jutaan. Setelah ditemukan komputer dan internet khususnya, pasar yang semula bersifat lokal bergeser menjadi pasar global. Pada era pasar global, juga berkembang media baru yang dikenal sebagai media interaktif atau digital, yang di samping memiliki sifat-sifat dasar seperti berkomunikasi melalui media interpersonal dan media massa, media digital juga memiliki sifat-sifat khusus antara lain sumber dan penerima pesan dapat berganti peran, pesan dapat disampaikan dan diterima dalam waktu yang bersamaan, dan tersebar luas tanpa batas ke seluruh dunia. Pada kondisi pasar global, peranan media interaktif menjadi keharusan untuk dimanfaatkan, di samping tetap melakukan integrasi dengan media konvensional.

Perubahan dramatis terjadi dari situasi pasar tradisional ke era global. Temuan konsep Integrated Marketing Communications/IMC dapat diyakini sebagai solusi strategis pada bisnis, pemasaran, dan komunikasi pemasaran dalam menghadapi permasalahan di pasar global. Prinsip-prinsip dasar IMC, the Global Building Blocks, pergeseran pola komunikasi dari masa penguasaan pasar di tangan produsen dan distributor ke tangan konsumen, dan strategi pendekatan alternatif Worldwide Learning, National Rseponsiveness, dan Global Integration, dapat menjadi acuan dasar dalam perencanaan strategis untuk menghadapi tantangan yang ada pada pasar global. Adapun pendekatan outside-in, closed loopplanning, pengelolaan big data, dan keterpaduan elemen-elemen pemasaran dan komunikasi pemasaran patut diterapkan dalam pola penyusunan rencana strategis Integrated Global Marketing Communications/ IGMC agar dapat mencapai kesuksesan organisasi atau perusahaan dalam mengantisipasi kondisi dan situasi yang terjadi di era pasar global.

\section{DAFTAR PUSTAKA}

Bolderston, A. (2008). Writing an Effective Literature Review. Journal of Medical Imaging and Radiation Sciences, 39, 86-92.

Chaffey, D., Chadwick, F. E. (2019). Digital Marketing: Strategy, Implementation and Practice (7th ed.). Harlow: Pearson Education Limited.

DeVito, J. A. (2001). The Interpersonal Communication Book (9th ed.) New York: Addison Wesley Longman, Inc.

Denney, A.S., \& Tewksbury, R.T. (2012). How to Write a Literature Review, Journal of Criminal Justice Education, DOI:10.1080/10511253.2012.730617

Duncan, T. (2005). Principles of Advertising \& IMC (2nd ed.). New York: McGraw-Hill/Irwin.

Estaswara, H. (2021). Strategic Communication dalam Perspektif Ilmu Komunikasi. CoverAge: Journal of Strategic Communication, 11(2), 7787.

Fill, C. \& Yeshin, T. (2001). Integrated Marketing Communications: 2001-2002. Woburn: Butterworth-Heinemann. 
Greenberg, E. \& Kates, K. (2014). Strategic Digital Marketing. New York: McGraw-Hill Education.

HoyerW. D., Macinnis, D. J., Pieters, R. (2018). Consumer Behavior (7th ed.). Singapore: Cengage Learning Asia Pte Ltd.

Kincaid, J. W. (2003). Customer Relationship Management: Getting It Right!. New Jersey: Prentice Hall, Inc.

Molenaar, C. (2002). The Future of Marketing: Practical Strategies for Marketers in the PostInternet Age. London: Pearson Education Limited.

Prayitno, S. \& Harjanto, R. (2017). Manajemen Komunikasi Pemasaran Terpadu: Bisnis, Pemasaran, dan Komunikasi Pemasaran, Seri\#1. Depok: Rajawali Pers, Divisi Buku Perguruan Tinggi.

Prayitno, S. \& Irwansyah. (2012). Marketing Communications in Global Society. Journalism and Mass Communication, 12(2):1149-1157.

Prayitno, S. (2020). Peranan 'Digital Branding' dalam Pengembangan Potensi Perusahaan. Gagasan Komunikasi untuk Negeri (1st ed.). Santoso, Edi (editor). 94-107. Purwokerto: Jurusan Ilmu Komunikasi Universitas Jenderal Soedirman.

Schults, D. E. \& Kitchen P. J. (2000). Communicating Globally: An Integrated Marketing Approach. Lincolnwood: NTC Business Books.

Schultz, D. E. \& Schultz, H. (2004). IMC The Next Generation: Five Steps for Delivering Value and Measuring Returns Using Marketing Communication. New York: McGraw-Hill Books.

Schultz, D. E., Tannenbaum, S. I. \& Lauternborn, R. F. (1993). Integrated Marketing Communications: Pulling It Together \& Making It Work. Lincolnwood: NTC Business Books.

Vivan, J. (1993). The Media of Mass Communication. (2nd ed.). Boston: Allyn and Bacon 